\title{
An exploratory investigation of investments and economic development in Saudi Arabia
}

\author{
Abdul Hafiz Henry James Jones \\ Management and Information Systems Department \\ University of Ha'il - College of Business Administration. Saudi Arabia
}

\section{HISTORICAL BACKGROUND: 1970 - 2013}

There is a consensus among researchers on the investment growth in Saudi Arabia from 1970 to 2013. They all agree that two major economic booms occurred due primarily oil revenues. They also agree that this was the catalyst that pushed the GDP of Saudi Arabia from approximately \$24 billion (SAR) in 1970 to \$279 billion (SAR) in 2013.

The first economic boom started in 1970 and reached its peak in 1982 covering a twelve-year span. According to the International Monetary Fund (IMF) statistics, the total investments ${ }^{1}$ in Saudi Arabia, over this twelve-year span, grew from $\$ 2.5$ billion (SAR) to $\$ 160$ billion (SAR). However, the sustainability of the growth driven by these huge investments was not viable considering that the GDP during that same twelve-year period was over three times the amount of these investments.

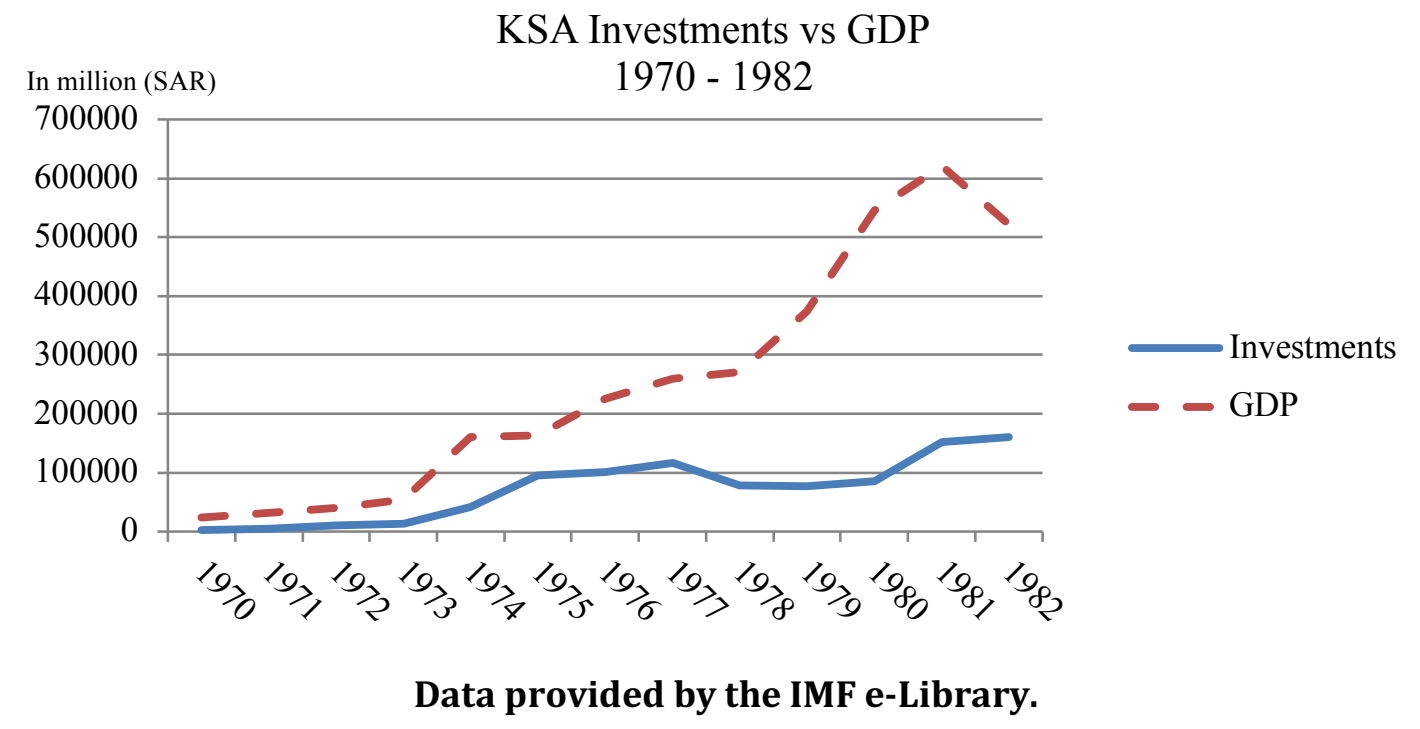

The IMF does not provide investment inflow data at the detail level, for example by province, region, or sector. This will be one of the main outputs of research funded by the endowment.

The second economic boom started in 2002 and is still present today based on the latest 2013 statistics. According to the International Monetary Fund (IMF) statistics the total investments in Saudi Arabia, over this current twelve-year span, grew from $\$ 81$ billion (SAR) to $\$ 2.8$ trillion (SAR). However, three major differences between the economic boom of 2002 and 1970 are the distribution of the investments, the ease of access to capital and the GDP.

1 The categories of investments included in the total investments are: FDI net inflows, primary income from FDI outflows, intellectual property receipts, and income from exports of goods and services, personal remittances received, grants, and reserves. 


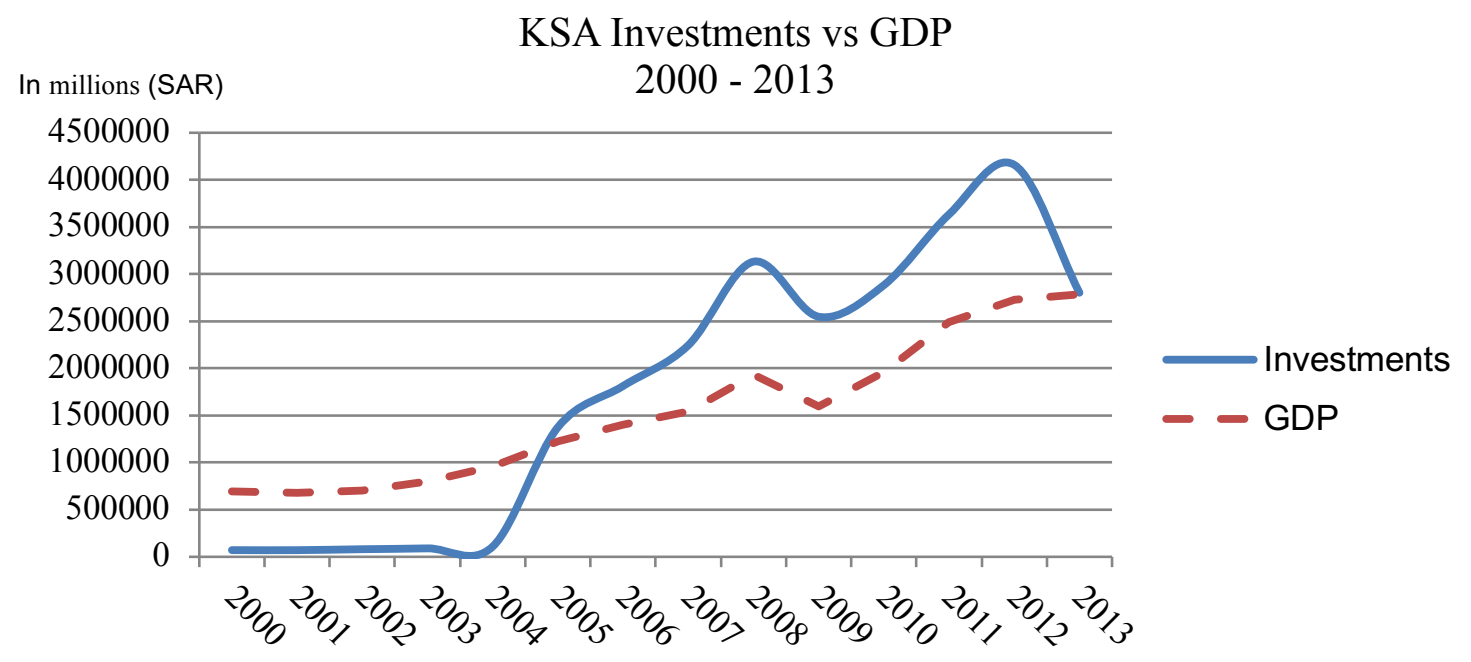

Data provided by the IMF e-Library

\section{The Distribution of Investments}

The bulk of investment inflows into Saudi Arabia generates from oil revenues it would be one's natural instinct to examine the annual budget of how those revenues are distributed out via the country's expenditures. Based on the numbers provided by the Saudi Arabia Monetary Agency (SAMA) the government expenditures were consistent year over year from 1970 to 2014 with respect to human resource development, transportation, and communications, health and social services, and infrastructure development.

The cost of living index as a proxy to investment inflows via economic growth shows a slight disparity among the seventeen major cities. Dammam is leading the increase with $34 \%$ and Ar'ar with the lowest percentage of increase of $16 \%$. The cost of living index is in no way an exact measure of how the investments are distributed, but it does serve as secondary confirmation of such.

This area of investment distributions is a key area of focus for research that will be sort with the endowment grant. This endowment will allow research in a more detailed way of how investments are distributed by provinces, regions, cities, and among key public and private sectors and industries.

\section{The Ease of Access to Capital}

An important note to highlight is the ease of access to capital from 1988 to 2013 took a dramatic shift. From 1988 to 1999 the rate at which money changed hands in Saudi Arabia 6 times on average. There was no data provided by SAMA prior to 1988. The Income Velocity of Money Table below includes M1, M2, and M3 categories combined from the money supply. From 2000 to 2013 the rate at which money changed hands in Saudi Arabia had dropped to 4.5 times. This $25 \%$ drop might not be considered significant if observed in isolation, but when looked at in conjunction with investment inflows between 2000 and 2013 it becomes very significant. Although the Saudi Industrial Development Fund (SIDF) was established in 1974, there is not enough data to compare the inflow of loans between the 1970 economic boom and the 2002 economic boom.

For the better part of the 2000 to 2013 period investment inflows in Saudi Arabia drastically exceeded the GDP so the expectation of easy access to capital should be safely assumed. However, this is not the case; the velocity of the money index shows another difference between the first economic boom in 1970 and the second economic boom starting 2002. This 
is also a clear indication that capital projects in the Kingdom were not as easy to secure as they once were in the 1970s.

The Income Velocity of Money

(non-oil sector)

1988 to 2013

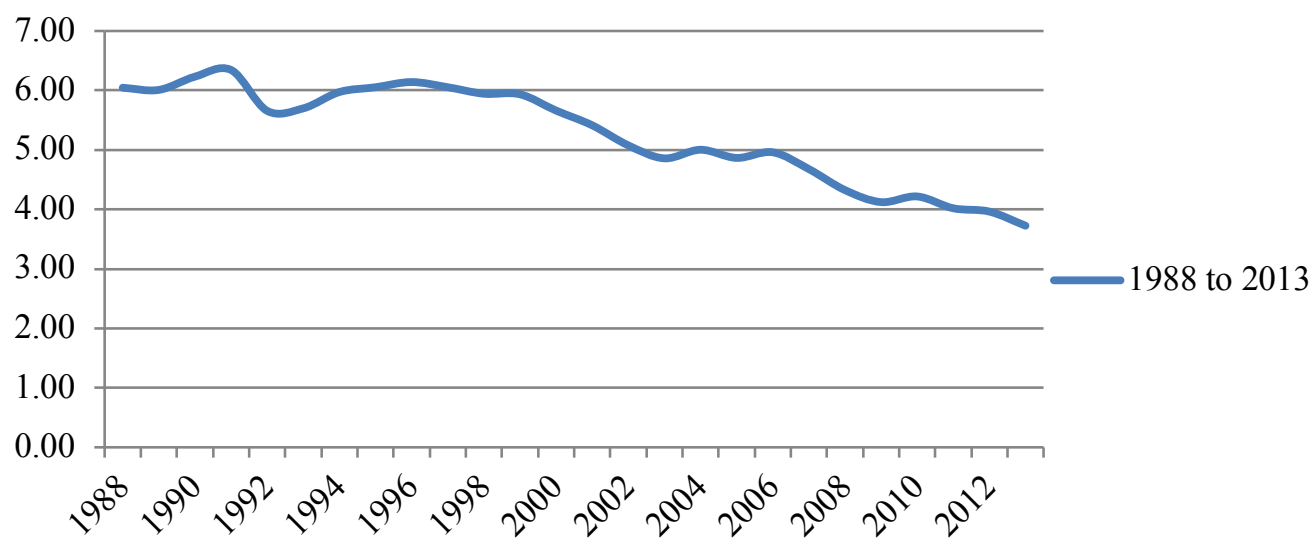

Data provided by SAMA - Saudi Arabia Monetary Agency

Given the change in investment activity in the 1970s compared to the 2000s in relation to the GDP, the cost of living index, and the money supply, all indications point to the plan to diversify.

\section{The Diversification Development Plan}

With the growth of investment inflows due primarily to oil revenues, Saudi Arabia moved to reduce its reliance on oil by diversifying its revenues in non-oil private sectors. The initial Five-Year Plan started in the early 70s and it has continued to roll over as objectives have been met and new objectives added. According to the Ministry of Economy and Planning, the key economic objectives are to:

1. To diversify the economic base with due emphasis on promising areas such as manufacturing industries, energy \& related derivatives, mining, tourism, and information technology industries.

2. To achieve balanced growth throughout all regions of the Kingdom.

3. To provide a favorable climate for the development of the private sector, and to encourage it to invest and play a leading role in the development process.

In reference to diversification, each sector had a plan for development. For example, the first plan which spanned from 1970 to 1974 focused on the diversification and development of manufacturing, mining, and infrastructure. From 1975 to 1979 diversification and development extended further into the manufacturing industry by leveraging FDI in the way of technology transfers. By1980 the aim was developing a healthy and educated workforce. In 1985 education, construction and banking became the primary areas focus along with further FDI concentration to strengthen the private sector.

The '90s brought a focus of defense with the advent of the Gulf Crisis. In addition to security, educational training, and the start of replacing expatriate workers with Saudi nationals or Saudization went into action. Between 2000 and 2004 diversification of services and further strengthening of the private via FDI became the planned goals. The diversification development plan from 1970 to 2000 led to a 5.6\% increase in the Non-Oil GDP. (AbdelRahman, 2001) 


\section{The Investments Impact on the GDP}

Saudi Arabia reports its GDP in two parts, oil, and non-oil sectors. The non-oil sector is further segmented by the private and government sectors. From 1970 to 2013 the GDP structure has remained constant with the Oil GDP representing about $44 \%$ of the total GDP.

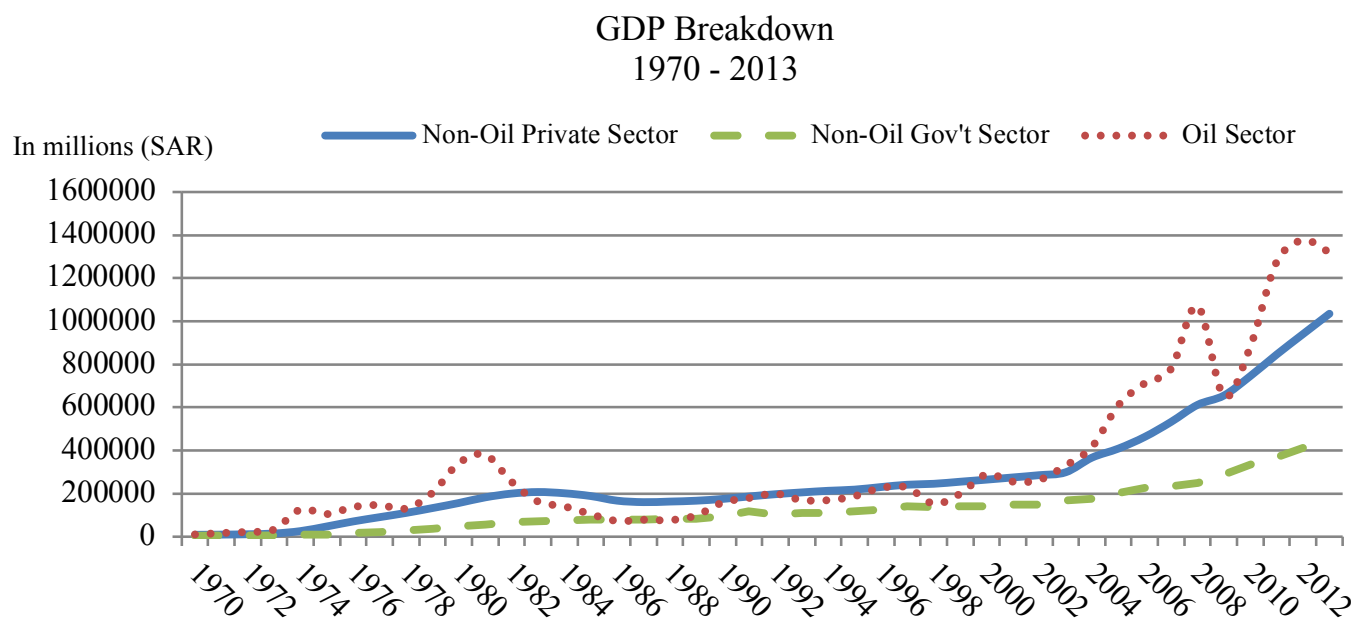

\section{Data provided by SAMA - Saudi Arabia Monetary Agency}

From a visual graphical representation of the GDP Breakdown from 1970 to 2013, it looks as though the Non-Oil GDP maintained a sustained level of growth starting from 1986 . However, when compared to the Oil GDP's sporadic growth year over year it shows a very different picture. Abdel-Rahman (2001) explains this cause of sporadic growth as supply-side shocks that have proven to be very destabilizing to the domestic economy of Saudi Arabia.

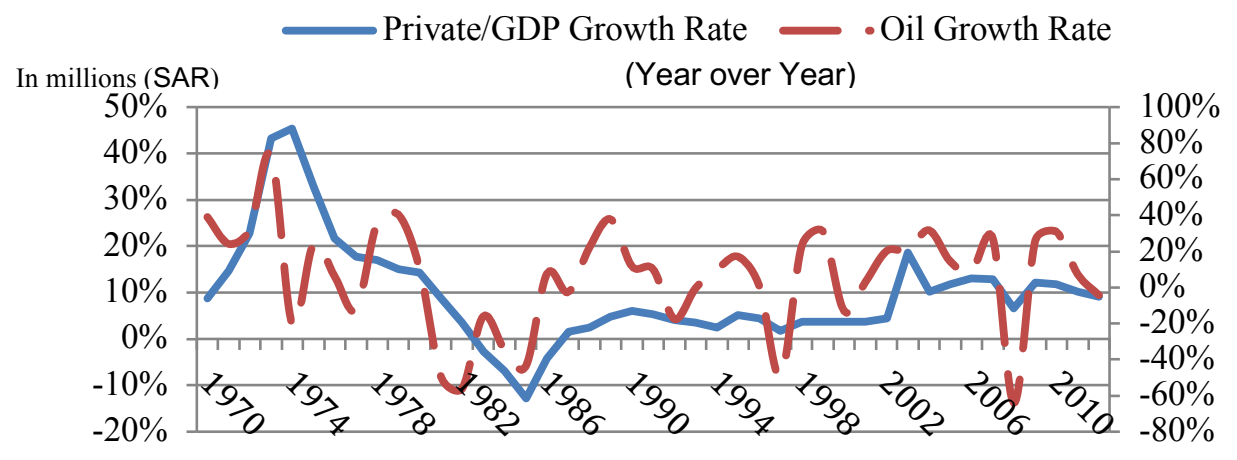

\section{Data provided by SAMA - Saudi Arabia Monetary Agency}

Abdel-Rahman (2001) makes the observation that the percentage growth in the Non-Oil and the private sectors show considerable contributions to the GDP at selected periods that coincide with the end of each Five-Year Diversification Plan. He states that this was one of the ways the Kingdom was able to mitigate the destabilizing supply-side shocks originating from the Oil Markets.

The significance of this research endowment becomes much greater from the point of reporting GDP contribution by various sectors that are beneath both the Non-Oil and the private sectors. Exports data at the granular level will provide a basis for examining the impact of investments on the Non-Oil and the contributions of the private sector to the GDP. 


\section{The Research Endowment Objectives}

The primary objective is to understand the nature and distributions of investments made in Saudi Arabia between 1970 and 2013. This is important in order to understand why something provinces and regions were able to benefit while other areas were not. The three secondary objectives of this research program proposal below are aimed at producing an optimized model for investment inflows and outflows in Saudi Arabia to attain sustained economic growth and competitiveness.

- To establish practical investment research that can be utilized in Saudi Arabia as well as other developing countries.

- To establish venues for the application of various types of investments in the public and private sectors of Saudi Arabia

- To establish a technological network containing the results or findings of investment research under the research endowment fund. The will allow the interested parties and stakeholders, the ease of extracting information related to the factors that impact investments related to their particular missions.

\section{The Research Approach}

The strategies that will allow the research endowment fund to achieve the previously mentioned objectives are based on a structured research process. The strategies are aimed to look at keeping the research endowment fund on the cutting edge of investment research that could possibly lead to the establishment of a research center for the study of foreign and domestic investments.

To establish practical foreign and domestic investment research that can be utilized in the public and private sectors of Saudi Arabia.

The research endowment fund would be the most appropriate institution for producing the required research for understanding the depth of foreign and domestic investments in Saudi Arabia. Many research papers will be developed covering the factors that relate to FDI inward and outwards flows, import and exports receipts on goods and services, intellectual property receipts, and other investments applied to the balance of payments. Inward flows are outside investments flowing into a country. While FDI outward flows are investments outside the country.

The approach will lead to established venues for the application of foreign and domestic investments in the public and private sectors of Saudi Arabia.

The research endowment fund will establish periodic workshops and conferences to introduce findings on foreign and domestic investments research from leading resident and nonresident experts in the field. Furthermore, a journal will be established for the sole purpose of publishing the center's work ensuring timely dissemination of the latest research findings.

To establish a technological network containing the results or findings of foreign and domestic investments research under the research endowment fund. This will allow the interested parties and stakeholders, the ease of extracting information related to the factors of foreign and domestic investments related to their particular missions.

The purpose of the network is to combine the foreign and domestic investments research findings, the application of current foreign and domestic investments activity in Saudi Arabia and the business community input, into a database that can be leveraged for economic strategic development and planning. 
What makes this database unique and significant is that the foreign and domestic investments research endowment fund's database will contain more than statistical surveys. It will contain research syntheses (meta-analysis), primary research (to include statistical surveys), and research related to managerial simulations of foreign and domestic investments location of choice given the moderating variables of political stability, investment levels, currency fluctuations, and domestic entrepreneurship.

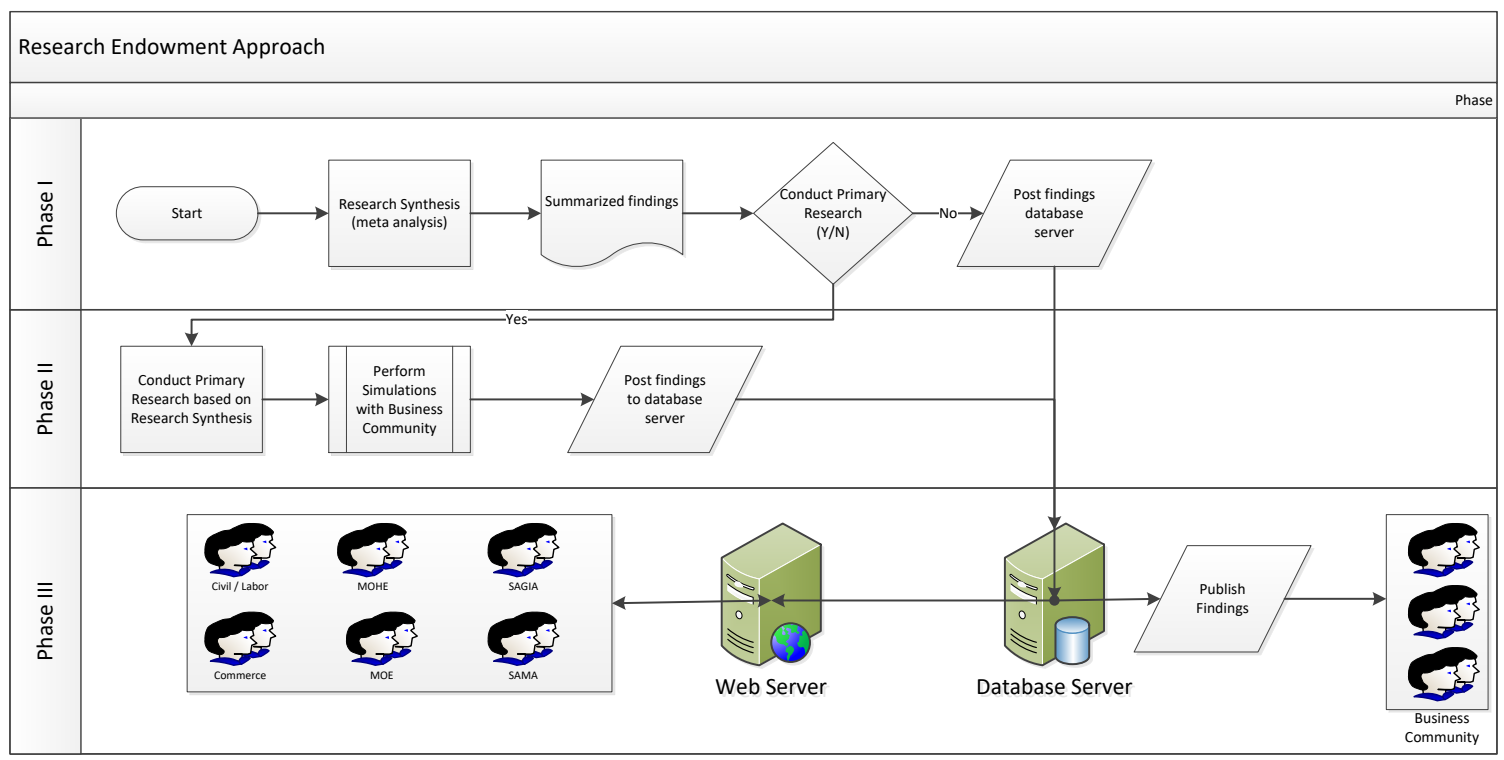

\section{The Research Endowment Benefits}

The benefits that the research endowment fund will provide are as follows

- Detailed foreign and domestic investments research in line with the Global Competitiveness Report 2018-2019

- Access to resident experts on International Trade and foreign and domestic investments conducting live workshops and conferences

- Access to the latest foreign and domestic investments research and global trends in international trade and business.

\section{Implementation Plan}

The plan for the research endowment fund will leverage the UOH College of Business key faculty and research network of foreign and domestic investments practitioners, academicians to ensure the plan outlined is executed.

The structure of the research endowment fund will be as follows:

1. A permanent governing committee for the assessment of scholarly researcher with proven experience in foreign and domestic investments research.

2. Under the guidance of the governing committee, multiple research task committees will be created for the production of the initial foreign and domestic investments research.

\section{METHODOLOGY}

The methodology of how the research endowment fund will deliver on practical foreign and domestic investments research will be based on research syntheses in all the factors that impact both foreign and domestic investments inward and outward flows. The purpose of the performing research syntheses prior to conducting primary research is present the state of foreign and domestic investments knowledge concerning the relation(s) of interest and to highlight important issues that prior FDI research has left unsolved. 
Another reason the research endowment will produce research syntheses in all factors impacting foreign and domestic investments as the first phase of its methodology is to allow the factors outlined in the GCI and the World Investment Report developed by United Nation Conference on Trade and Development (UNCTAD), to be measured against summarized literature in the field via meta-regression. This will provide the research endowment fund with a "clean slate" to perform primary research in the areas that impact sustained economic growth and productivity in Saudi Arabia. Furthermore, the findings from the research syntheses will allow the research endowment fund direct its resources in the areas that have been identified as having the greatest impact on foreign and domestic investments in Saudi Arabia.

Research simulations will be conducted based on the findings from both the research syntheses and primary research with managers (in participating countries) to further reinforce the research endowment fund's work with what is actually occurring in the business community with regards to international trade and foreign and domestic investments in particular. This will be in the special area of foreign investment inflows pertaining to the location of choice.

The workshops and conferences will also be conducted in alignment with the findings from both the research syntheses and primary research so that reinforcement of the areas of focus can be addressed and the interested public and private institutions in developing countries can benefit.

\section{SUMMARY}

This proposal highlighted the key areas that warrant further investigation at a more granular level. There is an underlying question that must be answered. This question requires in-depth analysis of the GDP, GDP contribution structure, real GDP growth, foreign and domestic investment inflows, and outflows. Furthermore, an in-depth investigation on the nature of foreign and domestic investment inflows and outflows to include FDI, import and exports, intellectual property receipts and payments as well as other balance of payment investment line-items.

All of these factors, if examined with proper due diligent research, will provide the current structure reflecting the impact of investments on the GDP in Saudi Arabia. In addition, it will also be the basis for a framework that answers the question:

Why some regions and provinces are benefitting from foreign and domestic investment inflows and outflows, while other regions and provinces are not?

\section{References}

Abdel-Rahman, A.-M. M. (2001). Economic Diversification in the Kingdom of Saudi Arabia (pp. 1-43). Riyadh. Alkhathlan, Khalid A. (2001). Have been the Development Plans in Saudi Arabia Achieving their Goals? A VAR Approach (pp. 1-44). Riyadh.

Buckley, Peter J., Devinney, Timothy M., and Louviere, Jordan J. (2007). Do managers behave the way theory suggests? A choice-theoretic examination of foreign direct investment location decision-making. , The Journal of International Business Studies, 38, 1069-1094.

http://www.sama.gov.sa/

www.imf.org/ 
IMF Investment Data from 1968 to 2013 (KSA)

Country Name Country Code Series Name

\begin{tabular}{|c|c|c|}
\hline Saudi Arabia & SAU & Foreign direct investment, net (BoP, current US\$̣) \\
\hline Saudi Arabia & SAU & Foreign direct investment, net inflows (\% of GDP) \\
\hline Saudi Arabia & SAU & Foreign direct investment, net inflows (BoP, current US\$) \\
\hline Saudi Arabia & SAU & Foreign direct investment, net outflows (\% of GDP) \\
\hline Saudi Arabia & SAU & Net capital account (BOP, current US\$) \\
\hline Saudi Arabia & SAU & Net errors and omissions (BOP, current US\$̦) \\
\hline Saudi Arabia & SAU & Net financial account (BoP, current US\$̧) \\
\hline Saudi Arabia & SAU & Portfolio Investment, net (BOP, current US\$\$) \\
\hline Saudi Arabia & SAU & Portfolio equity, net inflows (BOP, current US\$̧) \\
\hline Saudi Arabia & SAU & Primary income on FDI (current US\$̧) \\
\hline Saudi Arabia & SAU & Reserves and related items (BOP, current USȘ) \\
\hline Saudi Arabia & SAU & Charges for the use of intellectual property, payments (BOP, current US\$) \\
\hline Saudi Arabia & SAU & Charges for the use of intellectual property, receipts (BOP, current US\$̦) \\
\hline Saudi Arabia & SAU & Communications, computer, etc. (\% of service exports, BoP) \\
\hline Saudi Arabia & SAU & Communications, computer, etc. (\% of service imports, BoP) \\
\hline Saudi Arabia & SAU & Current account balance (\% of GDP) \\
\hline Saudi Arabia & SAU & Current account balance (BOP, current US\$) \\
\hline Saudi Arabia & SAU & Exports of goods and services (BOP, current USȘ) \\
\hline Saudi Arabia & SAU & Exports of goods, services and primary income (BOP, current US\$) \\
\hline Saudi Arabia & SAU & Goods exports (BoP, current US\$̦) \\
\hline Saudi Arabia & SAU & Goods imports (BoP, current US\$) \\
\hline Saudi Arabia & SAU & Imports of goods and services (BoP, current US\$) \\
\hline Saudi Arabia & SAU & Imports of goods, services and primary income (BOP, current US\$) \\
\hline Saudi Arabia & SAU & Insurance and financial services (\% of service exports, BoP) \\
\hline Saudi Arabia & SAU & Insurance and financial services (\% of service imports, BoP) \\
\hline Saudi Arabia & SAU & Net primary income (BOP, current US\$̧) \\
\hline Saudi Arabia & SAU & Net secondary income (BoP, current US\$) \\
\hline Saudi Arabia & SAU & Net trade in goods (BoP, current US\$) \\
\hline Saudi Arabia & SAU & Net trade in goods and services (BOP, current US\$) \\
\hline Saudi Arabia & SAU & Personal remittances, paid (current US\$̧) \\
\hline Saudi Arabia & SAU & Personal remittances, received (\% of GDP) \\
\hline Saudi Arabia & SAU & Personal remittances, received (current US\$) \\
\hline Saudi Arabia & SAU & Personal transfers, receipts (BOP, current US\$̧) \\
\hline Saudi Arabia & SAU & Primary income payments (BOP, current US\$) \\
\hline Saudi Arabia & SAU & Primary income receipts (BOP, current USȘ) \\
\hline Saudi Arabia & SAU & Secondary income receipts (BOP, current USȘ) \\
\hline Saudi Arabia & SAU & Secondary income, other sectors, payments (BOP, current US\$) \\
\hline Saudi Arabia & SAU & Service exports (BoP, current US\$̧) \\
\hline Saudi Arabia & SAU & Service imports (BoP, current US\$S) \\
\hline Saudi Arabia & SAU & Trade in services (\% of GDP) \\
\hline Saudi Arabia & SAU & Transport services (\% of service exports, Bop) \\
\hline Saudi Arabia & SAU & Transport services ( $\%$ of senvice imports, BoP) \\
\hline Saudi Arabia & SAU & Travel services (\% of service exports, BOP) \\
\hline Saudi Arabia & SAU & Travel services (\% of service imports, BOP) \\
\hline Saudi Arabia & SAU & Grants, excluding technical cooperation (BOP, current US\$̧) \\
\hline Saudi Arabia & SAU & Technical cooperation grants (BoP, current US\$) \\
\hline Saudi Arabia & SAU & Total reserves ( $\%$ of total external debt) \\
\hline Saudi Arabia & SAU & Total reserves (includes gold, current US\$) \\
\hline Saudi Arabia & SAU & Total reserves in months of imports \\
\hline Saudi Arabia & SAU & Total reserves minus gold (current US\$̦) \\
\hline
\end{tabular}

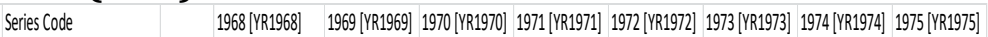
$\begin{array}{lllllllll}\text { BN.KLT.DNV.CD } & 0 & 0 & 0 & 0 & 0 & 0 & 0 & 0\end{array}$

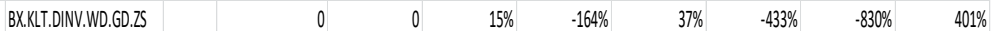

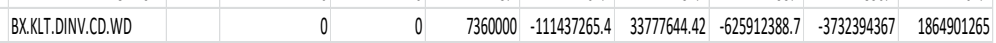
$\begin{array}{lllllllll}\text { BM.KLT.DIN.GD.75 } & 0 & 0 & 0 & 0 & 0 & 0 & 0 & 0\end{array}$ $\begin{array}{lllllllll}\text { BN.TRF.KOGT.CD } & 0 & 0 & 0 & 0 & 0 & 0 & 0 & 0\end{array}$ $\begin{array}{lllllllll}\text { BN.KACE.ENS.CD } & 0 & 0 & 0 & 0 & 0 & 0 & 0 & 0\end{array}$ $\begin{array}{lllllllll}\text { BN.FIN.TOTLCD } & 0 & 0 & 0 & 0 & 0 & 0 & 0 & 0\end{array}$ $\begin{array}{lllllllll}\text { BN.KLT.PTL.CD } & 0 & 0 & 0 & 0 & 0 & 0 & 0 & 0\end{array}$ $\begin{array}{lllllllll}\text { BX.PEF.TOTL.CD.WD } & 0 & 0 & 0 & 0 & 0 & 0 & 0 & 0\end{array}$ $\begin{array}{lllllllll}\text { BX.KLT.DREM.CD.DT } & 0 & 0 & 0 & 0 & 0 & 0 & 0 & 0\end{array}$ $\begin{array}{lllllllll}\text { BN.RES.NCL.CD } & 0 & 0 & 0 & 0 & 0 & 0 & 0 & 0\end{array}$ $\begin{array}{lllllllll}\text { BM.GSR.ROYL.CD } & 0 & 0 & 0 & 0 & 0 & 0 & 0 & 0\end{array}$ $\begin{array}{lllllllll}\text { BX.GSR.ROYLCD } & 0 & 0 & 0 & 0 & 0 & 0 & 0 & 0\end{array}$ $\begin{array}{lllllllll}\text { BX.GSR.CMCP.ZS } & 0 & 0 & 0 & 0 & 0 & 0 & 0 & 0\end{array}$ $\begin{array}{lllllllll}\text { BM.GSR.CMCP.ZS } & 0 & 0 & 0 & 0 & 0 & 0 & 0 & 0\end{array}$ $\begin{array}{lllllllll}\text { BN.CAB.XOKA.GD.7S } & 0 & 0 & 0 & 0 & 0 & 0 & 0 & 0\end{array}$ $\begin{array}{lllllllll}\text { BN.CAB.XOKA.CD } & 0 & 0 & 0 & 0 & 0 & 0 & 0 & 0\end{array}$ $\begin{array}{lllllllll}\text { BX.GSR.GNFS.CD } & 0 & 0 & 0 & 0 & 0 & 0 & 0 & 0\end{array}$ $\begin{array}{lllllllll}\text { BX.GSR.TOTLCD } & 0 & 0 & 0 & 0 & 0 & 0 & 0 & 0\end{array}$ $\begin{array}{lllllllll}\text { BX.GSR.MRCH.CD } & 0 & 0 & 0 & 0 & 0 & 0 & 0 & 0\end{array}$ $\begin{array}{lllllllll}\text { BM.GSR.MRCH.CD } & 0 & 0 & 0 & 0 & 0 & 0 & 0 & 0\end{array}$ $\begin{array}{lllllllll}\text { BM.GSP.GNFS.CD } & 0 & 0 & 0 & 0 & 0 & 0 & 0 & 0\end{array}$ $\begin{array}{lllllllll}\text { BM.GSR.TOTLCD } & 0 & 0 & 0 & 0 & 0 & 0 & 0 & 0\end{array}$ $\begin{array}{lllllllll}\text { BX.GSP.ISSF.Z2 } & 0 & 0 & 0 & 0 & 0 & 0 & 0 & 0\end{array}$ $\begin{array}{lllllllll}\text { BM.GSR.NSFF.2S } & 0 & 0 & 0 & 0 & 0 & 0 & 0 & 0\end{array}$ $\begin{array}{lllllllll}\text { BN.GSR.CCT.CD } & 0 & 0 & 0 & 0 & 0 & 0 & 0 & 0\end{array}$ $\begin{array}{lllllllll}\text { BN.TR.CURR.CD } & 0 & 0 & 0 & 0 & 0 & 0 & 0 & 0\end{array}$ \begin{tabular}{lllllllll} 
BN.GSR.MRCH.CD & 0 & 0 & 0 & 0 & 0 & 0 & 0 & 0 \\
\hline BNGSPGESSCD & 0 & 0 & 0 & 0 & 0 & 0 & 0 & 0
\end{tabular}

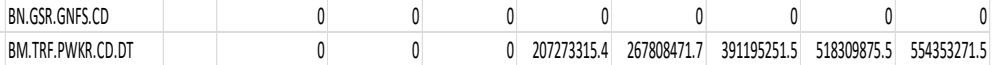
$\begin{array}{lllllllll}\text { BX.TFF.PWKR.DT.G.25 } & 0 & 0 & 0 & 0 & 0 & 0 & 0 & 0\end{array}$ $\begin{array}{lllllllll}\text { BX.TRF.PWKR.CD.DT } & 0 & 0 & 0 & 0 & 0 & 0 & 0 & 0\end{array}$ $\begin{array}{lllllllll}\text { BX.TFF.PWKR.CD } & 0 & 0 & 0 & 0 & 0 & 0 & 0 & 0\end{array}$ $\begin{array}{lllllllll}\text { BM.GSP.FCTY.CD } & 0 & 0 & 0 & 0 & 0 & 0 & 0 & 0\end{array}$ $\begin{array}{lllllllll}\text { BX.GSR.CCT.CD } & 0 & 0 & 0 & 0 & 0 & 0 & 0 & 0\end{array}$ $\begin{array}{lllllllll}\text { BX.TRF.CURR.CD } & 0 & 0 & 0 & 0 & 0 & 0 & 0 & 0\end{array}$ $\begin{array}{lllllllll}\text { BM.TRF.PRVT.CD } & 0 & 0 & 0 & 0 & 0 & 0 & 0 & 0\end{array}$ $\begin{array}{lllllllll}\text { BX.GSR.NFV.CD } & 0 & 0 & 0 & 0 & 0 & 0 & 0 & 0\end{array}$ $\begin{array}{lllllllll}\text { BM.GSP.NFSV.CD } & 0 & 0 & 0 & 0 & 0 & 0 & 0 & 0\end{array}$ $\begin{array}{lllllllll}\text { BG.GSR.NFSV.GD.7S } & 0 & 0 & 0 & 0 & 0 & 0 & 0 & 0\end{array}$ $\begin{array}{lllllllll}\text { BX.GSR.TAAN.ZS } & 0 & 0 & 0 & 0 & 0 & 0 & 0 & 0\end{array}$ $\begin{array}{lllllllll}\text { BM.GSR.TAAN.ZS } & 0 & 0 & 0 & 0 & 0 & 0 & 0 & 0\end{array}$ $\begin{array}{lllllllll}\text { BX.GSR.TRL.ZS } & 0 & 0 & 0 & 0 & 0 & 0 & 0 & 0\end{array}$ BM.GSR.TRLL.TS BX.GRT.EXTA.CD.WD BX.GRT.TECH.CD.WD FI.RES.TOTL.DT.ZS FI.RESTOTLLCD F.RES.TOTLMO FI.RES.KGLD.CD

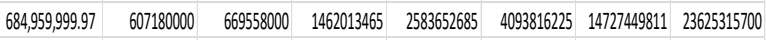
$\begin{array}{llllllll}542500000 & 487500000 & 542500000 & 1327371285 & 2383371285 & 3777412725 & 14152843311 & 23193205450\end{array}$ 


\begin{tabular}{|c|c|c|c|c|c|c|c|c|c|c|c|c|c|}
\hline Country Name & Country Code & Series Name & Series Code & 1976 [YR1976] 1 & 1977 [YR1977] & 1978 [YR1978] & 1979 [YR1979] 1 & 1980[YR1980] 1 & 1981 [YR1981] & 1982 [YR1982] 1 & 1983 [YR1983] 1 & 1984 [YR1984] 19 & 1985 [YR1985] \\
\hline Saudi Arabia & SAU & Foreign direct investment, net (BoP, current US\$) & BN.KLT.DINV.CD & 0 & 0 & 0 & 0 & 0 & 0 & 0 & 0 & 0 & 0 \\
\hline Saudi Arabia & SAU & Foreign direct investment, net inflows (\% of GDP) & BX.KLLT.DINV.WD.GD.ZS & $.62 \%$ & $106 \%$ & $69 \%$ & $-114 \%$ & $-194 \%$ & $353 \%$ & $728 \%$ & $384 \%$ & $407 \%$ & $47 \%$ \\
\hline Saudi Arabia & SAU & Foreign direct investment, net inflows (BoP, current US\$) & BX.KLT.DINV.CD.WD & -396600566.7 & 782964286 & 555954027.6 & -1270516965 & -3192312800 & 6498136246 & 11128383580 & 4943904678 & 4849863063 & 491422763.2 \\
\hline Saudi Arabia & SAU & Foreign direct investment, net oufflows (\% of GDP) & BM.KLT.DINV.GD.ZS & 0 & 0 & 0 & 0 & 0 & 0 & 0 & 0 & 0 & 0 \\
\hline Saudi Arabia & SAU & Net capital account (BOP, current US\$) & BN.TRF.KOGT.CD & 0 & 0 & 0 & 0 & 0 & 0 & 0 & 0 & 0 & 0 \\
\hline Saudi Arabia & SAU & Net errors and omissions (BOP, current US\$) & BN.KACEOMNSCD & 0 & 0 & 0 & 0 & 0 & 0 & 0 & 0 & 0 & 0 \\
\hline Saudi Arabia & SAU & Net financial account (BOP, current US\$) & BN.FIN.TOTL.CD & 0 & 0 & 0 & 0 & 0 & 0 & 0 & 0 & 0 & 0 \\
\hline Saudi Arabbia & SAU & Portfolio Investment, net ( $B$ BP, current US\$) & BN.KLT.PTXLLCD & 0 & 0 & 0 & 0 & 0 & 0 & 0 & 0 & 0 & 0 \\
\hline Saudi Arabbia & SAU & Portfolio equity, net inflows (BOP, current USSS) & BX.PEF.TOTLCD.WD & 0 & 0 & 0 & 0 & 0 & 0 & 0 & 0 & 0 & 0 \\
\hline Saudi Arabia & SAU & Primary income on FDI (current US\$) & BX.KLT.DREM.CD.DT & 0 & 0 & 0 & 0 & 0 & 0 & 0 & 0 & 0 & 0 \\
\hline Saudi Arabbia & SAU & Reserves and related items (BOP, current USSS) & BN.RES.INCL.CD & 0 & 0 & 0 & 0 & 0 & 0 & 0 & 0 & 0 & 0 \\
\hline Saudi Arabia & SAU & Charges for the use of intellectual property, payments (BOP, current US\$) & BM.GSR.ROYL.CD & 0 & 0 & 0 & 0 & 0 & 0 & 0 & 0 & 0 & 0 \\
\hline Saudi Arabia & SAU & Charges for the use of intellectual property, receipts (BOP, current USS) & BX.GSR.ROYLLCD & 0 & 0 & 0 & 0 & 0 & 0 & 0 & 0 & 0 & 0 \\
\hline Saudi Arabia & SAU & Communications, computer, etc. (\% of senvice exports, BOP) & BX.GSR.CMCP.ZS & 0 & 0 & 0 & 0 & 0 & 0 & 0 & 0 & 0 & 0 \\
\hline Saudi Arabia & SAU & Communications, computer, etc. (\% of service imports, BOP) & BM.GSR.CMCP.ZS & 0 & 0 & 0 & 0 & 0 & 0 & 0 & 0 & 0 & 0 \\
\hline Saudi Arabia & SAU & Current account balance (\% of GDP) & BN.CAB.XOKA.GD.ZS & 0 & 0 & 0 & 0 & 0 & 0 & 0 & 0 & 0 & 0 \\
\hline Saudi Arabbia & SAU & Current account balance (BOP, current US\$S) & BN.CAB.XOKA.CD & 0 & 0 & 0 & 0 & 0 & 0 & 0 & 0 & 0 & 0 \\
\hline Saudi Arabia & SAU & Exports of goods and services (BOP, current USSS) & BX.GSR.GNFS.CD & 0 & 0 & 0 & 0 & 0 & 0 & 0 & 0 & 0 & 0 \\
\hline Saudi Arabia & SAU & Exports of goods, services and primary income (BoP, current USS) & BX.GSR.TOTL.CD & 0 & 0 & 0 & 0 & 0 & 0 & 0 & 0 & 0 & 0 \\
\hline Saudi Arabia & SAU & Goods exports (BOP, current US\$) & BX.GSR.MRCH.CD & 0 & 0 & 0 & 0 & 0 & 0 & 0 & 0 & 0 & 0 \\
\hline Saudi Arabia & SAU & Goods imports (BOP, current USȘ) & BM.GSR.MRCH.CD & 0 & 0 & 0 & 0 & 0 & 0 & 0 & 0 & 0 & 0 \\
\hline Saudi Arabia & SAU & Imports of goods and services (BOP, current USȘ) & BM.GSR.GNFS.CD & 0 & 0 & 0 & 0 & 0 & 0 & 0 & 0 & 0 & 0 \\
\hline Saudi Arabia & SAU & Imports of goods, services and primary income (BoP, current USSS) & BM.GSR.TOTL.CD & 0 & 0 & 0 & 0 & 0 & 0 & 0 & 0 & 0 & 0 \\
\hline Saudi Arabia & SAU & Insurance and financial services (\% of service exports, BOP) & BX.GSR.INSF.ZS & 0 & 0 & 0 & 0 & 0 & 0 & 0 & 0 & 0 & 0 \\
\hline Saudi Arabia & SAU & Insurance and financial services (\% of service imports, BoP) & BM.GSR.INSF.ZS & 0 & 0 & 0 & 0 & 0 & 0 & 0 & 0 & 0 & 0 \\
\hline Saudi Arabia & SAU & Net primary income (BoP, current USSS) & BN.GSR.FTY.CD & 0 & 0 & 0 & 0 & 0 & 0 & 0 & 0 & 0 & 0 \\
\hline Saudi Arabia & SAU & Net secondary income (BOP, current US\$్) & BN.TRF.CURR.CD & 0 & 0 & 0 & 0 & 0 & 0 & 0 & 0 & 0 & 0 \\
\hline Saudi Arabia & SAU & Net trade in goods (BOP, current US\$) & BN.GSR.MRCH.CD & 0 & 0 & 0 & 0 & 0 & 0 & 0 & 0 & 0 & 0 \\
\hline Saudi Arabia & SAU & Net trade in goods and services (BoP, current US\$) & BN.GSR.GNFS.CD & 0 & 0 & 0 & 0 & 0 & 0 & 0 & 0 & 0 & 0 \\
\hline Saudi Arabbia & SAU & Personal remittances, paid (current US\$) & BM.TRF.PWKR.CD.DT & 988668579.1 & 1506355225 & 2844484375 & 3763943604 & 4094096191 & 5348102051 & 5346874512 & 5236254883 & 5284052246 & 5198590332 \\
\hline Saudi Arabbia & SAU & Personal remittances, received (\% of GDP) & BX.TRF.PWKR.DT.GD.ZS & 0 & 0 & 0 & 0 & 0 & 0 & 0 & 0 & 0 & 0 \\
\hline Saudi Arabia & SAU & Personal remittances, received (current US\$) & BX.TRF.PWKR.CD.DT & 0 & 0 & 0 & 0 & 0 & 0 & 0 & 0 & 0 & 0 \\
\hline Saudi Arabia & SAU & Personal transfers, receipts (BOP, current US\$) & BX.TRF.PWKR.CD & 0 & 0 & 0 & 0 & 0 & 0 & 0 & 0 & 0 & 0 \\
\hline Saudi Arabia & SAU & Primary income payments (BOP, current USSS) & BM.GSR.FCTY.CD & 0 & 0 & 0 & 0 & 0 & 0 & 0 & 0 & 0 & 0 \\
\hline Saudi Arabia & SAU & Primary income receipts (BoP, current US\$) & BX.GSR.FCTY.CD & 0 & 0 & 0 & 0 & 0 & 0 & 0 & 0 & 0 & 0 \\
\hline Saudi Arabia & SAU & Secondaryincome receipts (BOP, current USSS) & BX.TRF.CURR.CD & 0 & 0 & 0 & 0 & 0 & 0 & 0 & 0 & 0 & 0 \\
\hline Saudi Arabia & SAU & Secondary income, other sectors, payments (BOP, current US\$S) & BM.TRF.PRVT.CD & 0 & 0 & 0 & 0 & 0 & 0 & 0 & 0 & 0 & 0 \\
\hline Saudi Arabia & SAU & Service exports (BoP, current USSS) & BX.GSR.NFSV.CD & 0 & 0 & 0 & 0 & 0 & 0 & 0 & 0 & 0 & 0 \\
\hline Saudi Arabia & SAU & Service imports (BoP, current US\$) & BM.GSR.NFSV.CD & 0 & 0 & 0 & 0 & 0 & 0 & 0 & 0 & 0 & 0 \\
\hline Saudi Arabia & SAU & Trade in services (\% of GDP) & BG.GSR.NFSV.GD.ZS & 0 & 0 & 0 & 0 & 0 & 0 & 0 & 0 & 0 & 0 \\
\hline Saudi Arabia & SAU & Transport senvices (\% of service exports, BOP) & BX.GSR.TRAN.ZS & 0 & 0 & 0 & 0 & 0 & 0 & 0 & 0 & 0 & 0 \\
\hline Saudi Arabia & SAU & Transport senvices (\% of service imports, BOP) & BM.GSR.TRAN.ZS & 0 & 0 & 0 & 0 & 0 & 0 & 0 & 0 & 0 & 0 \\
\hline Saudi Arabia & SAU & Travel services (\% of service exports, BoP) & BX.GSR.TRVL.ZS & 0 & 0 & 0 & 0 & 0 & 0 & 0 & 0 & 0 & 0 \\
\hline Saudi Arabia & SAU & Travel services (\% of service imports, BOP) & BM.GSR.TRVL.ZS & 0 & 0 & 0 & 0 & 0 & 0 & 0 & 0 & 0 & 0 \\
\hline Saudi Arabia & SAU & Grants, excluding technical cooperation (BOP, current USSS) & BX.GRT.EXTA.CD.WD & 0 & 0 & 130000 & 180000 & 220000 & 0 & 0 & 300000 & 220000 & 240000 \\
\hline Saudi Arabia & SAU & Technical cooperation grants (BoP, current USS) & BX.GRT.,TECH.CD.WD & 1780000 & 5310000 & 5830000 & 5990000 & 8820000 & 13320000 & 14560000 & 14820000 & 15420000 & 17970000 \\
\hline Saudi Arabia & SAU & Total reserves (\% of total external debt) & FI.RES.TOTL.DT.ZS & 0 & 0 & 0 & 0 & 0 & 0 & 0 & 0 & 0 & 0 \\
\hline Saudi Arabia & SAU & Total reserves (includes gold, current US\$) & FI.RES.TOTLLCD & 27314906125 & 30410987954 & 20225539057 & 21611586189 & 26128869368 & 34051209542 & 31649062333 & 29040700546 & 26165376464 & 26506780884 \\
\hline Saudi Arabia & SAU & Total reserves in months of imports & FI.RES.TOTL.MO & 0 & 0 & 0 & 0 & 0 & 0 & 0 & 0 & 0 & 0 \\
\hline Saudi Arabia & SAU & Total reserves minus gold (current USS\$) & FI.RES.XGLD.CD & 26899741375 & 29902777004 & 19199725057 & 19273282189 & 23436622868 & 32235827042 & 29549149933 & 27287326546 & 24748429664 & 25003888884 \\
\hline
\end{tabular}




\begin{tabular}{|c|c|c|c|c|c|c|c|c|c|c|c|c|c|c|c|}
\hline Country Name & Country Code & Series Name & Series Code & 1986[KR1986] 1 & 1987] [YR1987] & 1988 [KR1988] & 1989 [YR1989] 1 & 1990(YR1990] 19 & 1991[[YR1991] 19 & 1992[[R1992] 1. & 1993 [YR1993] 1 & 1994 [YR1994] 1 & 1995 [YR1995] 1 & 1996[[R1996] 1 & 1997 [YR1997] \\
\hline Saudi Arabia & SAU & Foreign direct investment, net (BoP, current USSS) & BN.KLT.DINV.CD & 0 & 0 & 0 & 0 & 0 & 0 & 0 & 0 & 0 & 0 & 0 & 0 \\
\hline Saudi Arabia & SAU & Foreign direct investment, net inflows (\% of GDP) & BX.KLT.DNVV.WD.GD.25 & $111 \%$ & $-137 \%$ & $-37 \%$ & $.69 \%$ & $159 \%$ & $12 \%$ & $-6 \%$ & $103 \%$ & $26 \%$ & $-132 \%$ & $.71 \%$ & $184 \%$ \\
\hline Saudi Arabia & SAU & Foreign direct investment, net inflows (BOP, current USS) & BX.KLT.DINV.CD.WD & 965935919.1 & -1173333333 & .328000000 & .6533333333 .3 & 1861333333 & 160000000 & .78933333 .33 & 1367200000 & 3493333333.3 & -1874666667 & -1127466667 & 3039466667 \\
\hline Saudi Arabia & SAU & Foreign direct investment, net outflows (\%o o GDP) & BM.KLT.DINV.GD.7S & 0 & 0 & 0 & 0 & 0 & 0 & 0 & 0 & 0 & 0 & 0 & 0 \\
\hline Saudi Arabia & SAU & Net capital account (BOP, current USS') & BN.TRF.KOGT.CD & 0 & 0 & 0 & 0 & 0 & 0 & 0 & 0 & 0 & 0 & 0 & 0 \\
\hline Saudi Arabia & SAU & Neterrors and omissions (BOP, current USSS) & BN.KACEONS.CD & 0 & 0 & 0 & 0 & 0 & 0 & 0 & 0 & 0 & 0 & 0 & 0 \\
\hline Saudi Arabia & SAU & Net financial account (BoP, current USS) & BN.FIN.TOTL.CD & 0 & 0 & 0 & 0 & 0 & 0 & 0 & 0 & 0 & 0 & 0 & 0 \\
\hline Saudi Arabia & SAU & Porttolio Investment, net (BOP, current USS) & BN.KLT.PTXLLCD & 0 & 0 & 0 & 0 & 0 & 0 & 0 & 0 & 0 & 0 & 0 & 0 \\
\hline Saudi Arabia & SAU & Portfolio equity, net inflows (BOP, current USS) & BX.PEF.TOTLLCD.WD & 0 & 0 & 0 & 0 & 0 & 0 & 0 & 0 & 0 & 0 & 0 & 0 \\
\hline Saudi Arabia & SAU & Primary income on FDI (current USS\$) & BX.KLT.DREM.CD.DT & 0 & 0 & 0 & 0 & 0 & 0 & 0 & 0 & 0 & 0 & 0 & 0 \\
\hline Saudi Arabia & SAU & Resenves and related items (BOP, current USSS) & BN.RES.NCL.CD & 0 & 0 & 0 & 0 & 0 & 0 & 0 & 0 & 0 & 0 & 0 & 0 \\
\hline Saudi Arabia & SAU & Charges for the use of intellectual property, payments (BOP, curent USSS) & BM.GSR.ROYL.CD & 0 & 0 & 0 & 0 & 0 & 0 & 0 & 0 & 0 & 0 & 0 & 0 \\
\hline Saudi Arabia & SAU & Charges for the use of intellectual property, receipts (BOP, current USSS) & BX.GSR.ROYL.CD & 0 & 0 & 0 & 0 & 0 & 0 & 0 & 0 & 0 & 0 & 0 & 0 \\
\hline Saudi Arabia & SAU & Communications, computer, etcc. (\% of service expoots, BOP) & BX.GSR.CMCP.ZZS & 0 & 0 & 0 & 0 & 0 & 0 & 0 & 0 & 0 & 0 & 0 & 0 \\
\hline Saudi Arabia & SAU & Communications, computer, etc. (Yo of service imports, BOP) & BM.GSR.CMCP.ZS & 0 & 0 & 0 & 0 & 0 & 0 & 0 & 0 & 0 & 0 & 0 & 0 \\
\hline Saudi Arabia & SAU & Current account balance (\% of GDP) & BN. CAB.XOKA,GD.ZS & 0 & 0 & 0 & 0 & 0 & 0 & 0 & 0 & 0 & 0 & 0 & 0 \\
\hline Saudi Arabia & SAU & Currentaccount balance (BOP, urrent USSS) & BN.CAB.XOKA.CD & 0 & 0 & 0 & 0 & 0 & 0 & 0 & 0 & 0 & 0 & 0 & 0 \\
\hline Saudi Arabia & SAU & Exports of goods and services (BOP, current USS) & BX.GSR.GNFS.CD & 0 & 0 & 0 & 0 & 0 & 0 & 0 & 0 & 0 & 0 & 0 & 0 \\
\hline Saudi Arabia & SAU & Exports of goods, services and primary income (BoP, current USSS) & BX.GSR.TOTL.CD & 0 & 0 & 0 & 0 & 0 & 0 & 0 & 0 & 0 & 0 & 0 & 0 \\
\hline Saudi Arabia & SAU & Goods exports (BDP, current USSS) & BX.GSR.MRCH.CD & 0 & 0 & 0 & 0 & 0 & 0 & 0 & 0 & 0 & 0 & 0 & 0 \\
\hline Saudi Arabbia & SAU & Goods imports (BOP, current USSS) & BM.GSR.MRCH.CD & 0 & 0 & 0 & 0 & 0 & 0 & 0 & 0 & 0 & 0 & 0 & 0 \\
\hline Saudi Arabia & SAU & Imports of goods and services (BoP, current USS) & BM.GSR.GNFS.CD & 0 & 0 & 0 & 0 & 0 & 0 & 0 & 0 & 0 & 0 & 0 & 0 \\
\hline Saudi Arabia & SAU & Imports of goods, services and priman income (BOP, current US\$) & BM.GSR.TOTLCDD & 0 & 0 & 0 & 0 & 0 & 0 & 0 & 0 & 0 & 0 & 0 & 0 \\
\hline Saudi Arabia & SAU & Insurance and financial services (\% of service exports, BOP) & BX.GSR.INSF.ZS & 0 & 0 & 0 & 0 & 0 & 0 & 0 & 0 & 0 & 0 & 0 & 0 \\
\hline Saudi Arabia & SAU & Insurance and financial services (\% of service imports, BOP) & BM.GSR.INSF.7S & 0 & 0 & 0 & 0 & 0 & 0 & 0 & 0 & 0 & 0 & 0 & 0 \\
\hline Saudi Arabia & SAU & Net primany income (BOP, current USSS) & BN.GSR.FCTY.CD & 0 & 0 & 0 & 0 & 0 & 0 & 0 & 0 & 0 & 0 & 0 & 0 \\
\hline Saudi Arabia & SAU & Net secondaryincome (BOP, current USSS) & BN.TRF.CURR.CD & 0 & 0 & 0 & 0 & 0 & 0 & 0 & 0 & 0 & 0 & 0 & 0 \\
\hline Saudi Arabia & SAU & Net trade ingoods (BOP, current USSS') & BN.GSR.MRCH.CD & 0 & 0 & 0 & 0 & 0 & 0 & 0 & 0 & 0 & 0 & 0 & 0 \\
\hline Saudi Arabia & SAU & Net trade in goods and services (BOP, current USSS) & BN.GSR.GNFS.CD & 0 & 0 & 0 & 0 & 0 & 0 & 0 & 0 & 0 & 0 & 0 & 0 \\
\hline Saudi Arabia & SAU & Persona remittances, paid (current USS) & BM.TRF.PWKR.CD.DT & 4800000000 & 4928000000 & 6501333496 & 8530666992 & 11221333010 & 137728000000 & 13379200200 & 15696000000 & 18077867190 & 16593867190 & 15492533200 & 15014400390 \\
\hline Saudi Arabbia & SAU & Personal remittances, received (\%o of GDP) & BX.TRF.PWKR.DT.GD.ZS & 0 & 0 & 0 & 0 & 0 & 0 & 0 & 0 & 0 & 0 & 0 & 0 \\
\hline Saudi Arabia & SAU & Personal remittances, received (current USSS) & BX.TRE.PWKR.CD.DT & 0 & 0 & 0 & 0 & 0 & 0 & 0 & 0 & 0 & 0 & 0 & 0 \\
\hline Saudi Arabbia & SAU & Personal transfers, receipts (BOP, current USS) & BX.TRF.PWKR.CD & 0 & 0 & 0 & 0 & 0 & 0 & 0 & 0 & 0 & 0 & 0 & 0 \\
\hline Saudi Arabia & SAU & Primary income payments (BOP, current USS) & BM.GSR.FCYY.CD & 0 & 0 & 0 & 0 & 0 & 0 & 0 & 0 & 0 & 0 & 0 & 0 \\
\hline Saudi Arabbia & SAU & Primary vincome receipts (BOP, , urrent USSS) & BX.GSR.FCTY.CD & 0 & 0 & 0 & 0 & 0 & 0 & 0 & 0 & 0 & 0 & 0 & 0 \\
\hline Saudi Arabia & SAU & Secondary income receipts (BOP, current USȘ) & BX.TRF.CURR.CD & 0 & 0 & 0 & 0 & 0 & 0 & 0 & 0 & 0 & 0 & 0 & 0 \\
\hline Saudi Arabia & SAU & Secondary income, other sectors, payments (BOP, current US\$) & BM.TRF.PRVT.CD & 0 & 0 & 0 & 0 & 0 & 0 & 0 & 0 & 0 & 0 & 0 & 0 \\
\hline Saudi Arabia & SAU & Service exports (BOP, current USSS) & BX.GSR.NFSV.CD & 0 & 0 & 0 & 0 & 0 & 0 & 0 & 0 & 0 & 0 & 0 & 0 \\
\hline Saudi Arabia & SAU & Service imports (BOP, current USS) & BM.GSRRNFSV.CD & 0 & 0 & 0 & 0 & 0 & 0 & 0 & 0 & 0 & 0 & 0 & 0 \\
\hline Saudi Arabia & SAU & Trade in services (\% of GDP) & BG.GSR.NFFY.GD.ZS & 0 & 0 & 0 & 0 & 0 & 0 & 0 & 0 & 0 & 0 & 0 & 0 \\
\hline Saudi Arabia & SAU & Transport services (\% of service exports, BDP) & BX.GSR.TRAN.ZS & 0 & 0 & 0 & 0 & 0 & 0 & 0 & 0 & 0 & 0 & 0 & 0 \\
\hline Saudi Arabia & SAU & Transport services $1 \%$ of service imports, BoP) & BM.GSR.TRAN.ZS & 0 & 0 & 0 & 0 & 0 & 0 & 0 & 0 & 0 & 0 & 0 & 0 \\
\hline Saudi Arabia & SAU & Travel services (\% of service exports, Bop) & BX.GSR.TRVL.ZS & 0 & 0 & 0 & 0 & 0 & 0 & 0 & 0 & 0 & 0 & 0 & 0 \\
\hline Saudi Arabbia & SAU & Travel services (\% of service imports, BoP) & BM.GSR.TRVL.ZS & 0 & 0 & 0 & 0 & 0 & 0 & 0 & 0 & 0 & 0 & 0 & 0 \\
\hline Saudi Arabbia & SAU & Grants, excluding technical cooperation (BOP, current USS) & BX.GRT.EXTA.CD.WD & 930000 & 1210000 & 3030000 & 790000 & 430000 & 340000 & 690000 & 5780000 & 1880000 & 1910000 & 1360000 & 2170000 \\
\hline Saudi Arabbia & SAU & Technical cooperation grants (BOP, current USSS) & BX.GRT.TECH.CD.WD & 17670000 & 20220000 & 15790000 & 12850000 & 14230000 & 13450000 & 12170000 & 16000000 & 16640000 & 15080000 & 11580000 & 10660000 \\
\hline Saudi Arabia & SAU & Total reserves (\% of total external deat) & FI.RES.TOTL.DT.ZS & 0 & 0 & 0 & 0 & 0 & 0 & 0 & 0 & 0 & 0 & 0 & 0 \\
\hline Saudi Arabia & SAU & Total resenves (includes gold, current USSS) & FI.RES.TOTLCD & 20120402794 & 24909267580 & 22438243829 & 18590541066 & 13437138407 & 13298422865 & 7466613250 & 9223546274 & 9138920935 & 10399130293 & 16017719884 & 16210180707 \\
\hline Saudi Arabia & SAU & Total reserves in months of imports & FI.RES.TOTL.MO & 0 & 0 & 0 & 0 & 0 & 0 & 0 & 0 & 0 & 0 & 0 & 0 \\
\hline Saudi Arabbia & SAU & Total reserves minus gold (current USS) & FI.RES.XGLD.CD & 18323826394 & 22684343980 & 20552734829 & 1674755066 & 11667678407 & 11673287265 & 5934996250 & 7428118920 & 7377503935 & 8621627293 & 14320646884 & 14876421461 \\
\hline
\end{tabular}




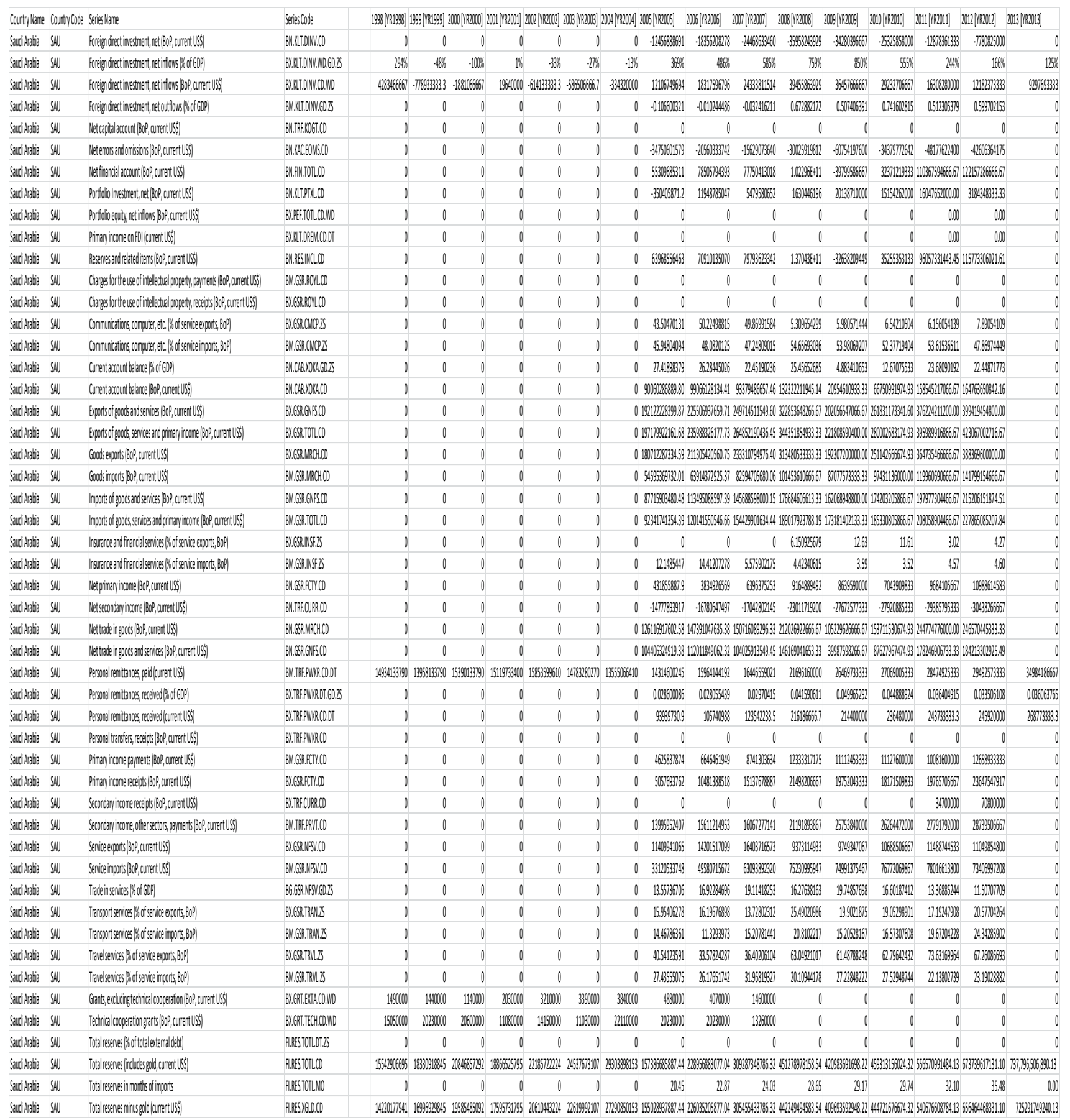


Saudi Arabia Monetary Agency (SAMA) Data from 1970 to 2013

\begin{tabular}{|c|c|c|c|c|c|}
\hline \multirow{3}{*}{ Year } & \multicolumn{5}{|c|}{ AT CURRENT PRICES (In SAR) } \\
\hline & \multirow[b]{2}{*}{ GDP } & \multirow{2}{*}{$\begin{array}{c}\text { Oil } \\
\text { Sector }\end{array}$} & \multicolumn{3}{|c|}{ Non-oil Sector } \\
\hline & & & Total & a) Private & b) Govt. \\
\hline 1970 & 23912 & 10390 & 13522 & 8903 & 4619 \\
\hline 1971 & 31864 & 17031 & 14833 & 9755 & 5078 \\
\hline 1972 & 39616 & 22450 & 17166 & 11425 & 5740 \\
\hline 1973 & 54921 & 33217 & 21704 & 14809 & 6896 \\
\hline 1974 & 160774 & 126320 & 34454 & 26078 & 8376 \\
\hline 1975 & 164016 & 104876 & 59140 & 47739 & 11401 \\
\hline 1976 & 225032 & 137999 & 87033 & 71060 & 15973 \\
\hline 1977 & 260110 & 146758 & 113352 & 90790 & 22562 \\
\hline 1978 & 271044 & 130552 & 140493 & 110417 & 30076 \\
\hline 1979 & 373778 & 203623 & 170155 & 132943 & 37212 \\
\hline 1980 & 544847 & 341641 & 203205 & 156501 & 46704 \\
\hline 1981 & 620730 & 380798 & 239932 & 182629 & 57303 \\
\hline 1982 & 522086 & 254737 & 267349 & 200171 & 67178 \\
\hline 1983 & 442611 & 163118 & 279493 & 207367 & 72126 \\
\hline 1984 & 417585 & 140671 & 276914 & 201676 & 75238 \\
\hline 1985 & 372408 & 104451 & 267957 & 188756 & 79201 \\
\hline 1986 & 318775 & 72666 & 246109 & 167301 & 78808 \\
\hline 1987 & 317478 & 78775 & 238703 & 160486 & 78217 \\
\hline 1988 & 322283 & 76738 & 245545 & 163120 & 82425 \\
\hline 1989 & 350325 & 98652 & 251672 & 167118 & 84554 \\
\hline 1990 & 430334 & 158693 & 271641 & 175387 & 96254 \\
\hline 1991 & 484853 & 179572 & 305281 & 186754 & 118527 \\
\hline 1992 & 501359 & 199856 & 301503 & 197270 & 104233 \\
\hline 1993 & 485630 & 170012 & 315617 & 205637 & 109980 \\
\hline 1994 & 494766 & 169438 & 325328 & 213191 & 112137 \\
\hline 1995 & 526004 & 187718 & 338285 & 218599 & 119686 \\
\hline 1996 & 581873 & 226476 & 355397 & 230509 & 124888 \\
\hline 1997 & 608802 & 228250 & 380552 & 241304 & 139248 \\
\hline 1998 & 536635 & 152829 & 383805 & 245603 & 138202 \\
\hline 1999 & 593955 & 198988 & 394967 & 255200 & 139767 \\
\hline 2000 & 697007 & 289165 & 407842 & 264873 & 142969 \\
\hline 2001 & 679163 & 255509 & 423654 & 275118 & 148536 \\
\hline 2002 & 699680 & 263511 & 436169 & 285682 & 150487 \\
\hline 2003 & 796561 & 330389 & 466172 & 298985 & 167187 \\
\hline 2004 & 961458 & 416734 & 544725 & 367195 & 177530 \\
\hline 2005 & 1220656 & 610392 & 610265 & 409002 & 201263 \\
\hline 2006 & 1400466 & 712219 & 688246 & 463365 & 224881 \\
\hline 2007 & 1547026 & 779672 & 767354 & 533050 & 234304 \\
\hline
\end{tabular}

\begin{tabular}{|c|c|c|c|c|c|}
\hline \multirow{2}{*}{ Year } & \multicolumn{4}{|c|}{ AT CURRENT PRICES (In SAR) } \\
\cline { 2 - 6 } & & Oil & \multicolumn{3}{|c|}{ Non-oil Sector } \\
\cline { 4 - 7 } & GDP & Sector & Total & a) Private & b) Govt. \\
\hline $\mathbf{2 0 0 8}$ & 1934298 & 1071590 & 862707 & 611976 & 250731 \\
$\mathbf{2 0 0 9}$ & 1596222 & 652762 & 943459 & 655347 & 288112 \\
$\mathbf{2 0 1 0}$ & 1960874 & 881820 & 1079053 & 745532 & 333522 \\
$\mathbf{2 0 1 1}$ & 2493365 & 1276416 & 1216949 & 845780 & 371169 \\
$\mathbf{2 0 1 2}$ & 2730840 & 1376576 & 1354264 & 940794 & 413470 \\
$\mathbf{2 0 1 3}$ & 2785481 & 1320248 & 1465233 & 1035049 & 430184 \\
\hline
\end{tabular}

